$4^{\text {th }}$ International Meeting on Calcitonin Gene-Related Peptide (CGRP)

TheScientificWorld (2001) 1(S1), 25

ISSN 1532-2246; DOI 10.1100/tsw.2001.425

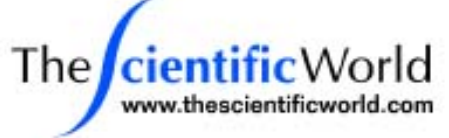

\title{
REPEATED SALMON CALCITONIN INJECTION LOWERS BODY WEIGHT AND BODY FAT
}

\author{
T.A. Lutz ${ }^{1}$, P.A. Rushing ${ }^{2}$, and T. Riediger ${ }^{1}$ \\ ${ }^{1}$ Institute of Veterinary Physiology, University of Zurich, Zurich, Switzerland; ${ }^{2}$ College of \\ Medicine, Department of Psychiatry, University of Cincinnati, Cincinnati, $\mathrm{OH}$
}

Single injection of the amylin-agonist salmon calcitonin (sCT) produces a potent, long-lasting $(>24 \mathrm{~h}$ at $5 \mu \mathrm{g} / \mathrm{kg}$ ) reduction in feeding being mediated by irreversible binding of sCT to amylin receptors. While chronic amylin administration decreases body weight gain in rats, similar experiments with sCT were not reported. We therefore tested the effect of repeated sCT injection on food intake and body weight. Once daily IP injection of sCT $(1.25,2.5 \mu \mathrm{g} / \mathrm{kg})$ reduced feeding in rats $(40 \%$ [w/w] fat diet) by $60[1.25 \mu \mathrm{g} / \mathrm{kg}]$ to $80[2.5 \mu \mathrm{g} / \mathrm{kg}] \%$ on day 1 and 35 to $55 \%$ on day 2. Thereafter, food intake was reduced by 20 to $30 \%$ vs. control. Over 1 week of treatment, body weight change was $-33 \mathrm{~g}[1.25 \mu \mathrm{g} / \mathrm{kg}]$ to $-37 \mathrm{~g}[2.5 \mu \mathrm{g} / \mathrm{kg}] \mathrm{vs}$. $-5 \mathrm{~g}$ in controls. Retroperitoneal fat was 30 to $35 \%$ lower than in controls. In a similar experiment, chow-fed rats were treated with sCT $(0.3,1.25,2.5 \mu \mathrm{g} / \mathrm{kg})$ once daily for 7 days. Food intake was reduced dose-dependently by sCT by 15 to $45 \%$ on days 1 and 2. Reduced food intake persisted (-20\% vs. control) throughout the study except for the lowest dose. Over 1 week of treatment, body weight change was $-10 \mathrm{~g}$ [2.5 $\mu \mathrm{g} / \mathrm{kg}],+7 \mathrm{~g}[1.25 \mu \mathrm{g} / \mathrm{kg}],+13 \mathrm{~g}[0.3 \mu \mathrm{g} / \mathrm{kg}]$ and $+17 \mathrm{~g}$ [control]. Retroperitoneal fat was reduced by $25[1.25 \mu \mathrm{g} / \mathrm{kg}]$ to $45[2.5 \mu \mathrm{g} / \mathrm{kg}] \%$ vs. control. We conclude that repeated sCT treatment potently lowers food intake in rats fed chow or a high-fat diet. Decreased food intake lead to a reduction in body weight and retroperitoneal fat mass. 

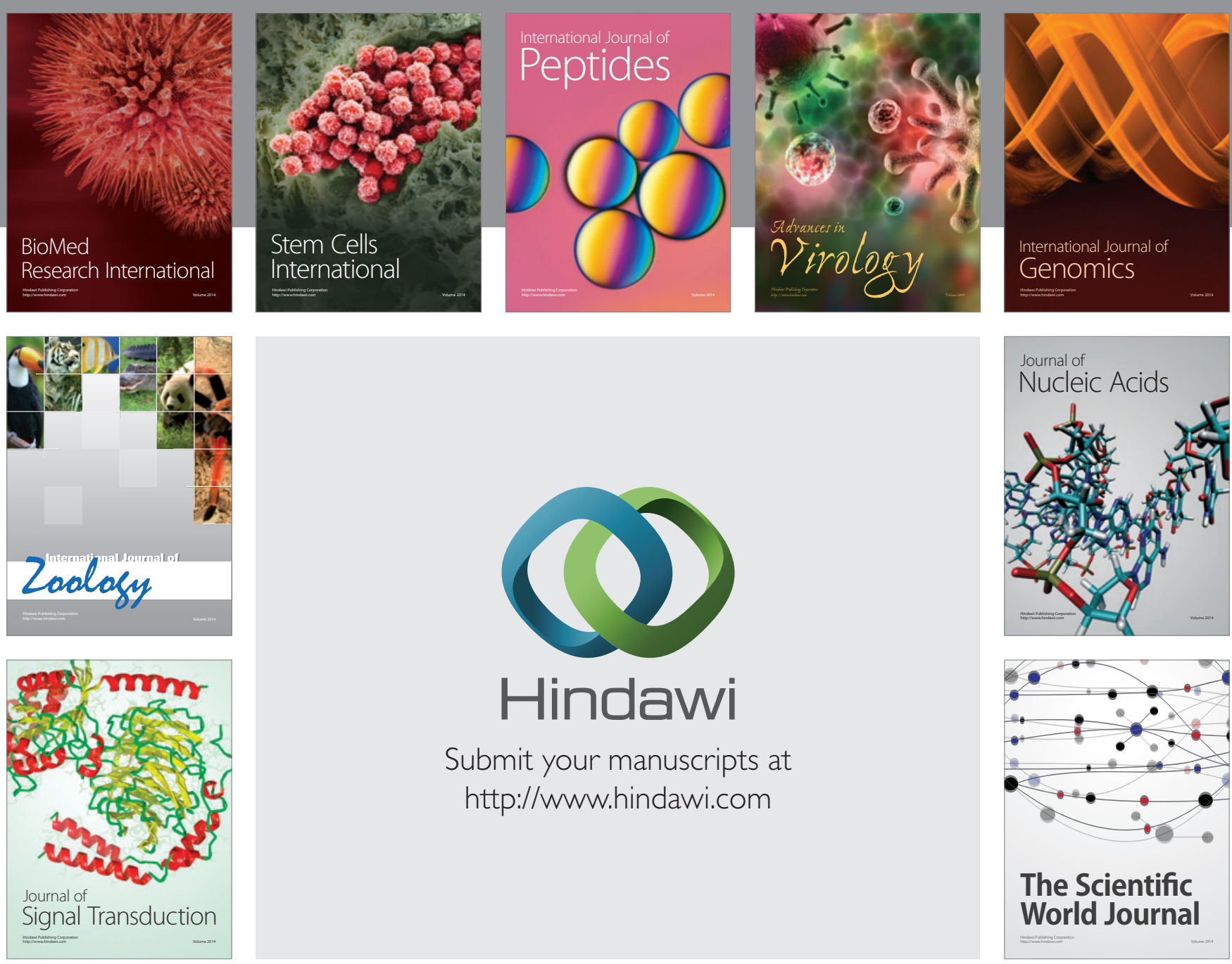

Submit your manuscripts at

http://www.hindawi.com
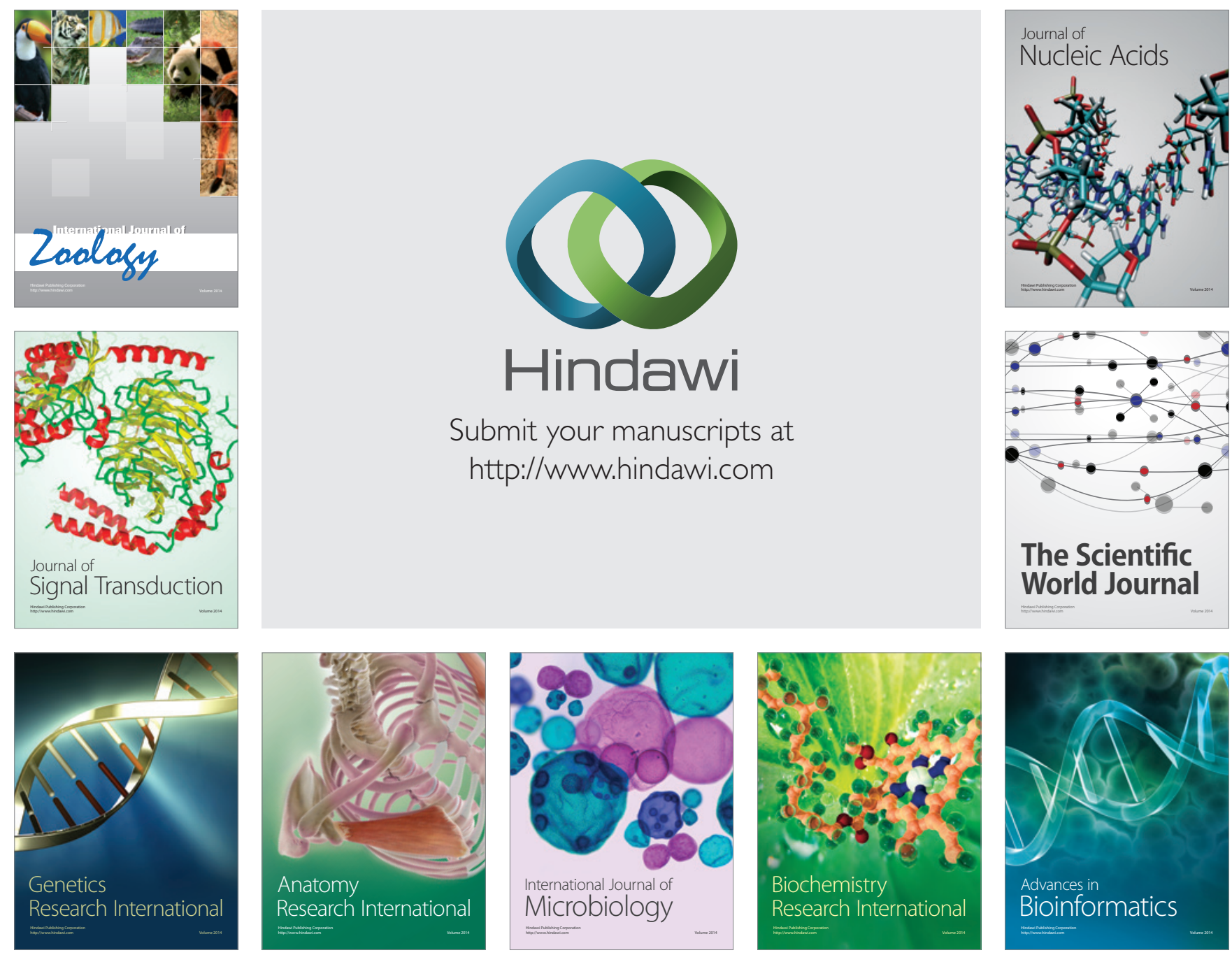

The Scientific World Journal
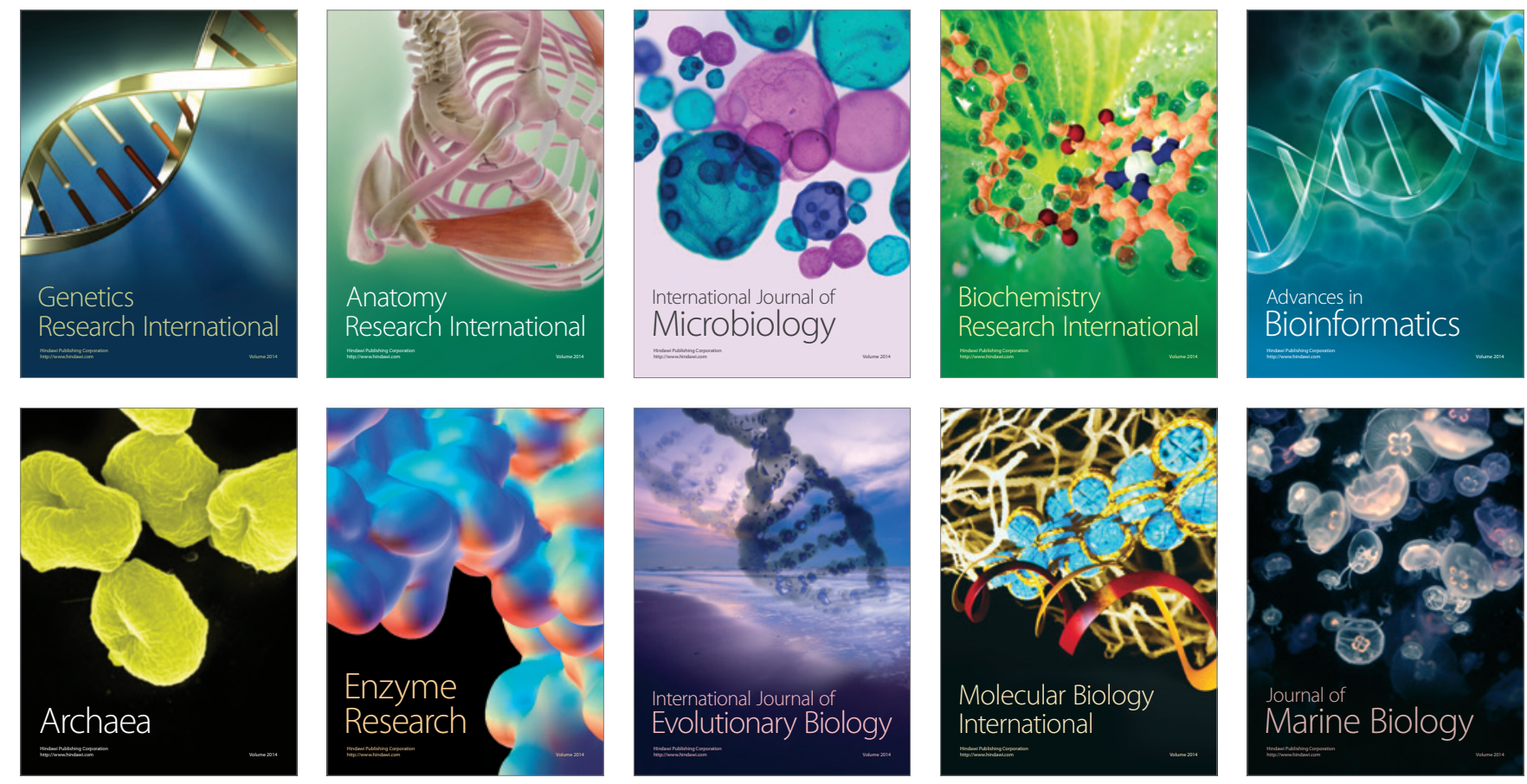